\title{
Distribution and reproductive biology of the Electric ray Discopyge tschudii Heckel, 1846 in San Matías Gulf, Northern Patagonia, Argentina
}

\author{
Marilú Estalles ${ }^{1,2}$, Nidia Marina Coller ${ }^{1,3}$, Edgardo Ernesto Di Giácomo ${ }^{1,3}$ and \\ María Raquel Perier ${ }^{1,3}$
}

\begin{abstract}
The Electric ray Discopyge tschudii is distributed in the Southwest Atlantic from southern Brazil to southern Argentina and in the Southeast Pacific from Peru to southern Chile. The main threat to this species is fishing. Discopyge tschudii is noncommercial and individuals caught are discarded on board. The present study analyzes the distribution and the morphological and reproductive characteristics of this ray in San Matías Gulf (SMG), Argentina. A total of 1087 individuals were analyzed. The species presented an aggregate distribution, with the main concentrations in the northern and eastern areas of SMG, at depths below $100 \mathrm{~m}$. Males ranged from 9 to $43 \mathrm{~cm}$ and females from 11 to $38 \mathrm{~cm}$. The species presented sexual dimorphism. Males were larger and heavier than females and also matured at larger sizes. Size at $50 \%$ of maturity was estimated at $30 \mathrm{~cm}$ for males and $21 \mathrm{~cm}$ for females. A total of 199 embryos were sampled and the proportion of sexes showed no significant differences from the expected 1:1. The number of embryos per female varied from 1 to 12 . The most frequent values were 2 and 5. Length at birth was estimated at $82.17 \pm 3.87 \mathrm{~mm}$. Based on our findings, we hypothesize that the electric ray D. tschudii completes its reproductive cycle in SMG.
\end{abstract}

La raya eléctrica Discopyge tschudii se distribuye, en el Atlántico Sudoccidental, desde el sur de Brasil hasta el sur de Argentina y en el Pacifico Sudoriental desde Perú al sur de Chile. La principal amenaza para la especie es la pesca. Es una especie sin valor comercial y debido a esto los ejemplares capturados por las embarcaciones pesqueras son descartados a bordo. En el presente estudio se analizan la distribución espacial y las características morfológicas y reproductivas de la especie en el Golfo San Matías (GSM), Argentina. Un total de 1087 ejemplares fueron analizados. La especie presentó una distribución agregada, encontrándose las principales concentraciones en el sector norte y este del GSM a profundidades menores a los $100 \mathrm{~m}$. Los machos midieron entre 9 y $43 \mathrm{~cm}$ de largo total y las hembras entre 11 y $38 \mathrm{~cm}$. La especie exhibió dimorfismo sexual, siendo los machos más grandes, más pesados y presentando mayores tallas de madurez que las hembras. La talla de madurez a la cual el 50\% de la población alcanzó la madurez sexual fue estimada en $30 \mathrm{~cm}$ en machos y $21 \mathrm{~cm}$ en hembras. Se analizaron 199 embriones. Las proporciones de sexos de los embriones no mostraron diferencias significativas de lo esperado 1:1. El número de embriones por hembra varió de 1 a 12, siendo los valores más frecuentes 2 y 5 . La talla de nacimiento fue estimada en $82,17 \pm 3,87 \mathrm{~mm}$. De acuerdo a nuestros resultados se hipotetiza que $D$. tschudii completa su ciclo reproductivo en el golfo.

Key words: Apron ray, Narcinidae, Southwest Atlantic, Torpedinoidei.

\section{Introduction}

The electric rays Discopyge tschudii Heckel, 1846 and the recently described Discopyge castelloi Menni, Rincón \& García, 2008 are the only two members of the genus Discopyge (family Narcinidae). Both species are found in the Argentine continental shelf (Menni et al., 2008). However, the distribution of $D$. tschudii is broader, covering an area of more than 7000 km (Pequeño \& Lamilla, 1993). Discopyge tschudii is found in the Southwest Atlantic from southern Brazil to southern Argentina and in the Southeast Pacific from Peru to southern Chile (Figueiredo, 1977; Menni \& Gosztonyi, 1982; Menni \& López, 1984; Pequeño et al., 1988).

According to the zoogeographic scheme proposed for the Southwest Atlantic, D. tschudii belongs to the Magellanic Province and it is grouped with the fish assemblage that

\footnotetext{
${ }^{1}$ Instituto de Biología Marina y Pesquera “Alte. Storni”, Güemes 1030, (8520), San Antonio Oeste, Río Negro, Argentina. ml.estalles@conicet.gov.ar/; mariluestalles@gmail.com

${ }^{2}$ Consejo Nacional de Investigaciones Científicas y Técnicas (CONICET), Av. Rivadavia 1917 C1033AAJ CABA, Argentina.

${ }^{3}$ Universidad Nacional del Comahue, Buenos Aires 1400, Neuquén, Argentina.nmcoller@yahoo.com.ar; edgardodigiacomo@gmail.com; raquelperier@gmail.com
} 
composes the mixed fauna of the inner shelf (Menni \& Gosztonyi, 1982; Menni \& López, 1984; Menni et al., 2010). It is found mainly in coastal waters below $120 \mathrm{~m}$ (Menni \& Gosztonyi, 1982; Menni \& López, 1984; Menni \& Stehmann, 2000; Menni et al., 2010).

The conservation status of $D$. tschudii is "Near Threatened" in the Red List of Endangered Species of the IUCN (Massa et al., 2004a). However, the population inhabiting the Southwest Atlantic is considered "Vulnerable" due to the remarkable decrease in its abundance during 19941999 (Massa et al., 2004b). The main threat to this species is fishing. Discopyge tschudii is noncommercial and individuals caught are discarded on board (Massa et al., 2004a; Tamini et al., 2006).

Little is known about the biological aspects of this ray. In the bottom trawl fishery of San Matías Gulf $\left(41^{\circ}-42^{\circ} \mathrm{S} ; 64^{\circ}\right.$ $\left.65^{\circ} \mathrm{W}\right), D$. tschudii is captured as bycatch together with other 18 species of skates and rays. The common hake, Merluccius hubbsi, is the target species of this fishery (Di Giácomo \& Perier, 1992) and D. tschudii is discarded on board due to the lack of economic value. The aim of this study was to analyze the distribution and the morphological and reproductive characteristics of this electric ray in San Matías Gulf.

\section{Material and Methods}

This study was performed using data collected from two different sources: bottom trawl surveys (aiming to assess the common hake and other demersal fish resources) and onboard observers on commercial vessels (Onboard Observer Program). Onboard observers collected the data during February and March 2006 and April and March 2007.

Bottom trawl surveys were carried out covering the area of San Matías Gulf (SMG) during spring (October to December) in 1986, 1995, and 1996 and from 2004 to 2007. In each survey, a variable number of hauls (35-40) of 30 minutes each were performed at a depth ranging from 20 to $175 \mathrm{~m}$. Vessels were equipped with 96 -ft commercial bottom trawls. Up to 2005, surveys were carried out following a random stratified design which divided the gulf into six strata (Fig. 1). During 2006 and 2007, the design of the surveys was changed and a systematic one was adopted. In this work, and in order to compare between surveys, the hauls performed during 2006 and 2007 were assigned to one stratum in accordance with the scheme shown in figure 1. Bottom trawl surveys will be referred as REDE plus the year of the survey (e.g. REDE 1986, REDE 2007). The name REDE comes from the Spanish translation of demersal resources (Recursos Demersales), which are the target fishes of the surveys (Di Giácomo, 1992; Di Giácomo \& Perier, 1991a; Perier \& Di Giácomo, 2002a, 2002b).

Data coming from another bottom trawl survey called GALLO 1986 were also analyzed. This survey covered the northern coast of SMG during October 1986. A total of 33 hauls of 30 minutes each were performed at a depth ranging from 20 to $130 \mathrm{~m}$. Hauls were performed in strata I, V, and VI, according to the design described in figure 1 . The vessel was

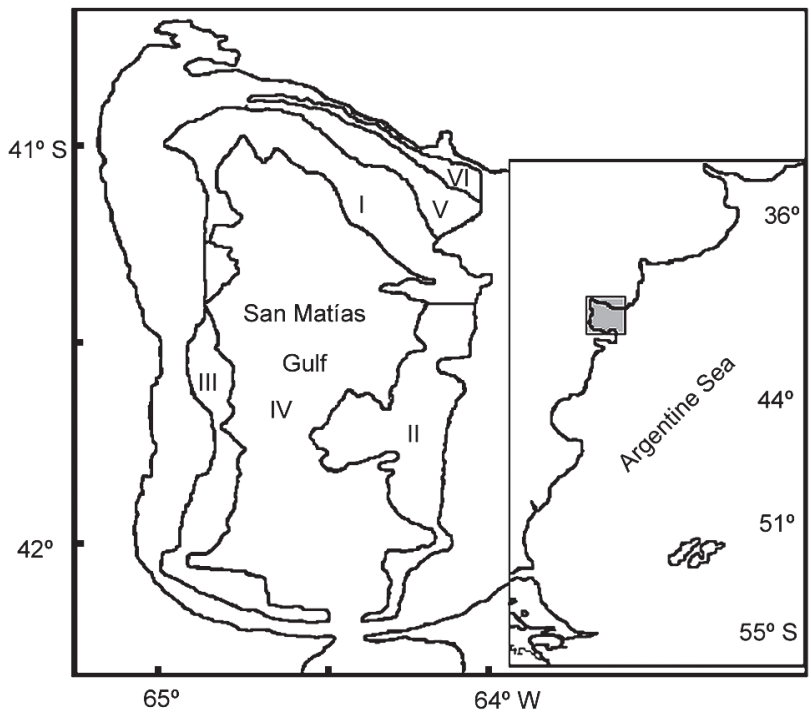

Fig. 1. Study area and design of bottom trawl surveys. Strata I, II, and III: 90-130 m; stratum IV: >130 m; stratum V: 50-89 m and stratum VI: $20-49 \mathrm{~m}$.

also equipped with a $96-\mathrm{ft}$ commercial bottom trawl. The aim of this survey was to assess the biomass of the stock of the holoceplan fish Callorhinchus callorhynchus (Di Giácomo \& Perier, 1991b). The name of the survey, GALLO, comes from "pez gallo", the Spanish common name of the target species of the survey.

\section{Distribution}

The spatial and bathymetric distributions of $D$. tschudii were analyzed using the data collected during bottom trawl surveys (REDEs and GALLO 1986). These distributions were inferred estimating the proportion and mean number of individuals per haul in each stratum. The spatial and bathymetric distributions were analyzed grouping surveys into three decades: the 1980's, the 1990's and the 2000's, because each series of surveys was separated by almost ten years.

For individuals collected during REDEs 2004-2007, differences in the proportion of males and females and in the proportion of mature and immature specimens were assessed by the $\chi^{2}$ test (Zar, 1984). Comparisons were made for the whole sample and in each stratum. In addition, the length frequency structures of the individuals sampled in each stratum were analyzed and compared. Curves were compared with a Kolmogorov-Smirnov goodness of fit test (Sokal \& Rohlf, 1987). Differences were considered significant when $\mathrm{P}<0.05$. These surveys (REDEs 2004-2007) were selected because sex and total length had been recorded in all the individuals sampled. Whenever possible, the maturity condition of the individuals was also assessed. If the maturity condition was not possible to record, it was inferred from the estimated $\mathrm{TL}_{50 \%}$ (see below). Individuals were considered mature if their total length (TL) was larger than or equal to the estimated $\mathrm{TL}_{50 \%}$. Otherwise, individuals were considered immature. 


\section{Morphology and reproduction}

The morphology and reproductive characteristics of $D$. tschudii were analyzed from individuals collected during REDEs 2004-2007 and by onboard observers. Whenever possible, sex, total length (TL) in $\mathrm{cm}$, disc width (DW) in $\mathrm{cm}$, and total weight (TW) in g were recorded for each individual. Total length was measured from the tip of the rostrum to the tip of the tail and DW as the maximum distance between the edges of the pectoral fins (Francis, 2006). The TL-TW and TL-DW relationships were estimated for each sex and compared with a $t$-test (Zar, 1984). Data were log-transformed to compare TL-TW relationships. The hypothesis of isometric growth $(b=3)$ was assessed for each sex following the procedure described by Pauly (1984). In addition, body growth was considered positive allometric if $b>3$ and negative allometric if $b<3$ (Pauly, 1984).

A subsample of individuals was randomly selected for the maturity assessment. Males were classified into three maturity stages according to the rigidity and length of the myxopterygia or claspers (Holden \& Raitt, 1975; Stehmann, 2002): immature, when claspers did not reach the margin of the pectoral fin; maturing, when claspers exceeded the pectoral fins but were flexible (semi- calcified); and mature, when claspers were longer than pectoral fins and rigid (fully calcified) (Holden \& Raitt, 1975; Stehmann, 2002). Clasper length $\left(\mathrm{L}_{C}\right)$ was measured with a 1-mm precision from the posterior margin of the cloacae to its tip (Compagno, 1984).

Females were classified into four maturity stages: immature, when they presented undeveloped ovaries with no oocytes differentiated and thread-like oviducts; maturing, when they presented developing ovaries with oocytes becoming differentiated and widened oviduct; mature when they presented fully developed reproductive tracts with yolked oocytes in their ovaries and without embryos in their uterus; and mature with embryos when they caried ova or embryos in their uterus (Stehmann, 2002).

Length at which $50 \%$ of the rays reached maturity $\left(\mathrm{TL}_{50 \%}\right)$ was estimated fitting a logistic model to the proportion of mature males and females in each length interval of one $\mathrm{cm}$ of TL. The model used was $P=1 / 1\left(1+\exp ^{(-r(\mathrm{TL}-\mathrm{TL} 50 \%))}\right)$, in which $P$ is the proportion of mature rays at a given length-class interval, $r$ is a fitted parameter, TL is the length-class interval for which the proportion of mature individuals is estimated, and $\mathrm{TL}_{50 \%}$ is the length-class interval at which $50 \%$ of the rays are mature. The model was fitted with FISHPARM 3.05 (Prager et al., 1989).

The number of embryos, sex, total length $\left(\mathrm{TL}_{e}\right)$ in $\mathrm{mm}$, and total weight in $\mathrm{g}\left(\mathrm{W}_{e}\right)$ were recorded. When present, the maximum diameter of the external yolk sac was recorded in $\mathrm{mm}$, in fresh condition. Differences in the proportion of males and females were assessed by the $\chi^{2}$ test (Zar, 1984). The relationship between the TL of a female and the number of embryos in its uterus was estimated using an exponential function. The model used was $N e=a \times \exp ^{(b * T L)}$, where $N e$ is the number of embryos, $a$ and $b$ are fitted parameters, and $T L$ is the total length in $\mathrm{cm}$ of the pregnant female. The model was fitted with FISHPARM 3.05 (Prager et al., 1989). The relationship between $\mathrm{TL}_{e}$ and $\mathrm{W}_{e}$ was also estimated. Size and weight at birth were estimated as the mean size and weight of fully developed embryos (Capapé et al., 2001).

\section{Results}

\section{Distribution}

The electric ray, D. tschudii, was found mainly in the northern and eastern areas of SMG in strata II, V, and VI (Table 1 and Fig. 2). The presence of this species was recorded from 10 to $160 \mathrm{~m}$ depth. However, $98 \%$ of the individuals were found below $100 \mathrm{~m}$. The proportion of individuals in each stratum varied depending on the decade. During the 1980's, the greatest proportion of individuals was found in stratum VI, during the 1990's in stratum V and during the 2000's in stratum II. In all decades, individuals were poorly represented in strata III and IV (Fig. 2). The highest mean number of individuals per haul was recorded in stratum VI during the 1980 's. During the 1990's, the mean number of individuals was low in all strata. During the 2000's the mean number of individuals increased again but the highest value was recorded in stratum II. Unfortunately, no hauls were performed in stratum VI during this decade (Table 1).

A total of 159 hauls were performed during REDEs 20042007. The species was recorded in $21 \%$ of these hauls $(n=33)$, although more than $90 \%$ of them were found only in 10 hauls. A total of 968 individuals were recorded. Males dominated the sample $\left(\mathrm{n}_{\text {males }}=533 ; \mathrm{n}_{\text {females }}=435 ; \chi^{2}=9.92 ;\right.$ d.f. $\left.=1 ; P<0.05\right)$ and were more abundant than females in stratum II $\left(\chi^{2}=37.9\right.$; d.f. $=1 ; P<0.05)$. However, females were more abundant in stratum $\mathrm{V}\left(\chi^{2}=22.1 ;\right.$ d.f. $\left.=1 ; P<0.05\right)$. Mature individuals

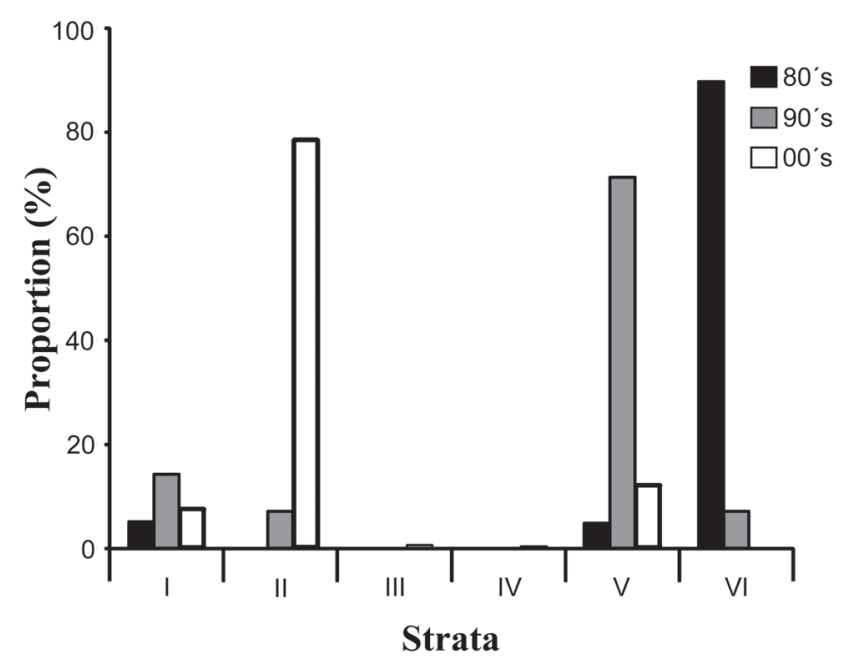

Fig.2. Proportion of individuals recorded in each stratum during bottom trawl surveys. Surveys carried out in the 1980's: REDE 1986 and Gallo 1986; surveys carried out in the 1990's: REDE 1995 and 1996; surveys carried out in the 2000's: REDEs 2004 to 2007. 
Table 1. Mean number of individuals per haul recorded in each stratum during surveys. Surveys carried out in the 1980's: REDE 1986 and Gallo 1986; surveys carried out in the 1990's: REDE 1995 and 1996; surveys carried out in the 2000's: REDEs 2004 to 2007.

\begin{tabular}{|c|c|c|c|c|c|c|c|c|c|c|c|}
\hline \multirow[b]{3}{*}{ Decade } & \multicolumn{11}{|c|}{ Stratum } \\
\hline & $\mathrm{I}$ & II & & III & & IV & & $\mathrm{V}$ & $\bar{V}$ & $\mathrm{~V}$ & VI \\
\hline & Mean DS & Mean & DS & Mean & DS & Mean & DS & Mean & DS & Mean & DS \\
\hline 80 's & $\begin{array}{ll}1.6 & 3.7\end{array}$ & 0 & 0 & 0 & 0 & 0 & 0 & 8 & 6.9 & 34.3 & 29.0 \\
\hline 90's & $0.1 \quad 0.3$ & 0.05 & 0.2 & 0 & 0 & 0 & 0 & 1 & 2.2 & 0.1 & 0.4 \\
\hline 00 's & $\begin{array}{ll}2.4 & 0.4 \\
\end{array}$ & 28.6 & 61.3 & 0.2 & 0.4 & 0.1 & 0.4 & 8.6 & 20.3 & - & - \\
\hline
\end{tabular}

dominated the sample of males and females $\left(\mathrm{n}_{\text {mature }}=333 ; \chi^{2}=\right.$ 33.2; d.f. $=1 ; P<0.001$ for males and $\mathrm{n}_{\text {mature }}=323 ; \chi^{2}=102.2$; d.f. $=1 ; P<0.001$ for females). Mature males were more abundant than immature ones in stratum II $\left(\chi^{2}=34.2 ;\right.$ d.f. $=1$; $P<0.05)$. However, no differences were found in stratum $\mathrm{V}$ $\left(\chi^{2}=0.01 ;\right.$ d.f. $\left.=1 ; P>0.05\right)$. Mature females dominated strata II and V $\left(\chi^{2}=51.9 ;\right.$ d. $f=1 ; P<0.001$ for stratum II and $\chi^{2}=52.3$; d.f. $=1 ; P<0.001$ for stratum V). For males, the length frequency structures of the individuals collected in strata II and $\mathrm{V}$ differed significantly $\left(D=0.38 ; n_{1}=465 ; n_{2}=63 ; P<0.05\right)$. Males larger than $30 \mathrm{~cm}$ TL predominated in stratum II. In contrast, males smaller than $30 \mathrm{~cm}$ TL predominated in stratum V (Fig. 3). For females, no significant differences were found among curves $\left(D=0.15 ; n_{1}=293 ; n_{2}=130 ; P>0.05 ;\right.$ Fig. 3$)$. For strata I, III, and IV, the number of individuals recorded was too low to make comparisons.

\section{Morphology and reproduction}

A total of 564 males and 523 females were sampled. Males ranged from 9 to $43 \mathrm{~cm}$ TL and weighed between 15 and $1135 \mathrm{~g}$. Females ranged from 11 to $38 \mathrm{~cm}$ TL and weighed between 20 and $710 \mathrm{~g}$ (Fig. 4). The TL-TW relationships differed significantly between sexes ( $t=2.1 ;$ d.f. $=1032 ; P<0.05$; Fig. 5 ). Males were heavier than females of the same length. Both sexes presented a negative allometric growth $(b=2.89 ; t=5.2 ;$ d. $f .=$ 554; $P<0.0001$ for males and $b=2.84 ; t=6.6$; $d . f .=478 ; P<$ 0.0001 for females). The TL-DW relationships also differed significantly between sexes ( $t=3.8 ;$ d.f. $=154 ; P<0.001$; Fig. 6$)$. Males presented wider discs than females of the same length.

From a total of 506 males, 58 were classified as immature (11.5\%), 166 as maturing (32.8\%) and 282 as mature (55.7\%). All the individuals smaller than $22 \mathrm{~cm}$ TL were immature. Maturing individuals ranged from 23 to $37 \mathrm{~cm}$ TL. Mature males were 26 to $43 \mathrm{~cm}$ TL. All the individuals larger than 37 $\mathrm{cm}$ TL were mature (Fig. 7). Length at maturity $\left(\mathrm{TL}_{50 \%}\right)$ was estimated at $30 \mathrm{~cm}$ TL $\left(\mathrm{R}^{2}=0.98\right.$; Fig. 8$)$.

From a total of 419 females, 85 were classified as immature (20.3\%), 19 as maturing (4.5\%) and 315 as mature (75.2\%). A total of 62 of the mature ones were carrying embryos or ova in their uterus (19.7\%). Immature females ranged from 11 to 31 $\mathrm{cm}$ TL, maturing from 18 to $32 \mathrm{~cm} \mathrm{TL}$, and mature between 19 to $38 \mathrm{~cm}$ LT. Length at maturity $\left(\mathrm{TL}_{50 \%}\right)$ was estimated at $21 \mathrm{~cm}$ $\mathrm{TL}\left(\mathrm{R}^{2}=0.98\right.$; Fig. 8$)$.

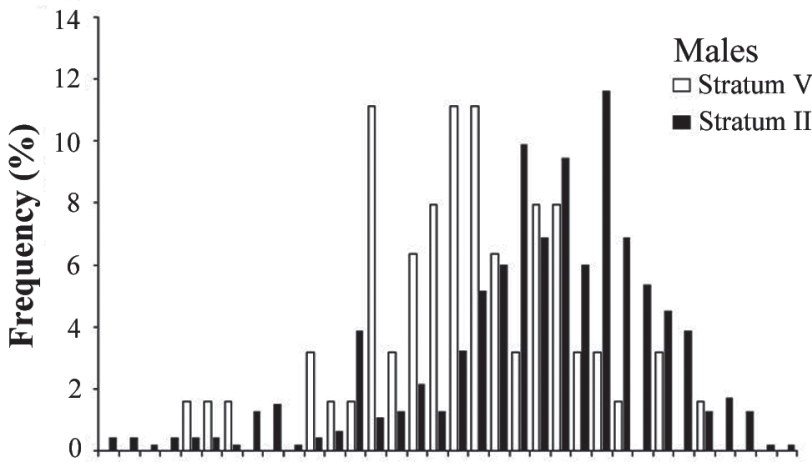

b

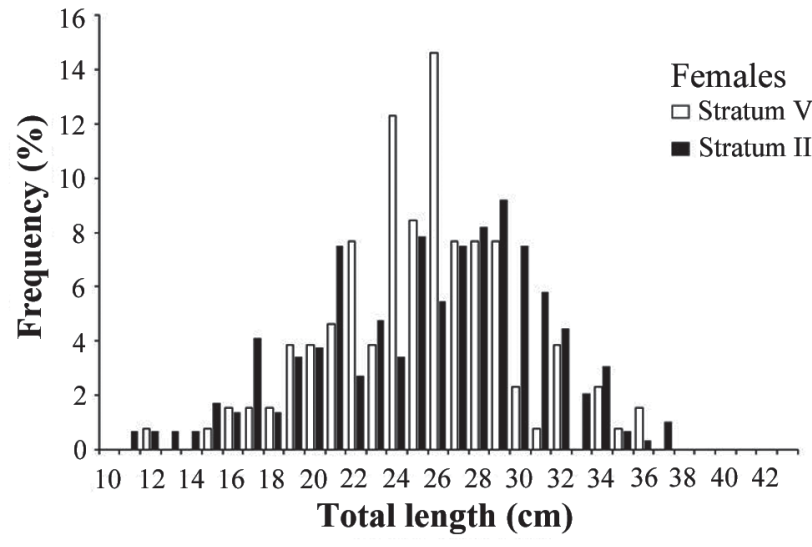

Fig. 3. Comparison of the length frequency distributions of the individuals collected during the bottom trawl surveys REDEs 2004- 2007. a) Males; b) Females.

A total of 199 embryos were sampled. The male:female proportion showed no significant differences from the expected $1: 1\left(\mathrm{n}=124 ; \chi^{2}=0.81 ;\right.$ d.f. $\left.=1 ; P>0.05\right)$. The number of embryos per female varied from 1 to 12 . The most frequent values were 2 and 5. The number of embryos in the uterus increased with the total length of the female (Fig. 9). Embryos ranged from 39 to $90 \mathrm{~mm} \mathrm{TL}$ and $\mathrm{W}_{e}$ varied between 0.85 and $10.98 \mathrm{~g}$. The relationship between $\mathrm{TL}_{e}$ and $\mathrm{W}_{e}$ is shown in figure 10. At sizes larger than $75 \mathrm{~mm} \mathrm{TL} e_{e}$, the external yolk sac was already consumed (Fig. 11). A total of 43 embryos completely developed, without carrying external yolk sac, were sampled. The mean $\mathrm{TL}_{e}$ at birth was estimated at $82.17 \pm 3.87$ $\mathrm{mm}$ and the mean $\mathrm{W}_{e}$ at $8.86 \pm 1.42 \mathrm{~g}$.

\section{Discussion}

The present study constitutes the first analysis of the distribution and morphological and reproductive characteristics of the electric ray Discopyge tschudii in San Matías Gulf(SMG). The species presented an aggregate distribution, with the main concentrations at depths below $100 \mathrm{~m}$. Our findings are consistent with reports of other areas of the Argentine and Chilean Seas, where the species is found from the intertidal zone up to a depth 


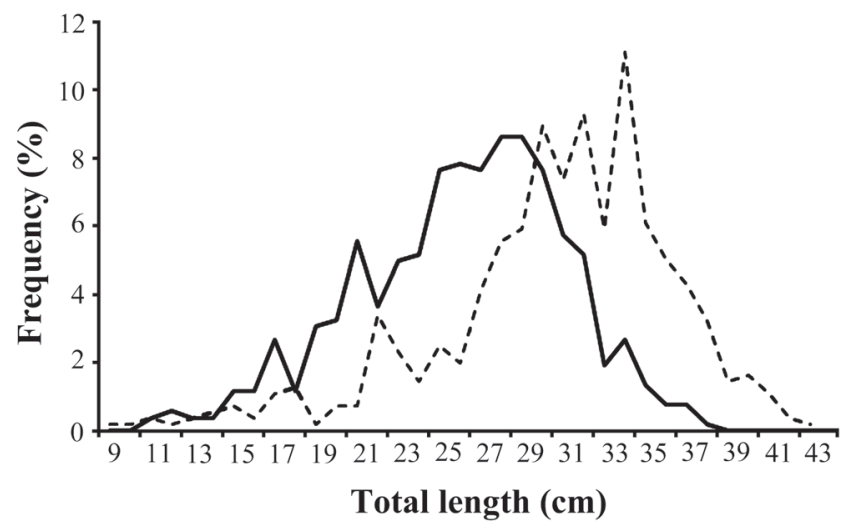

Fig. 4. Size frequency distribution of Discopyge tschudii sampled during 2004-2007. Males (dotted line) $\mathrm{n}=564$ and females (continuous line) $\mathrm{n}=523$.

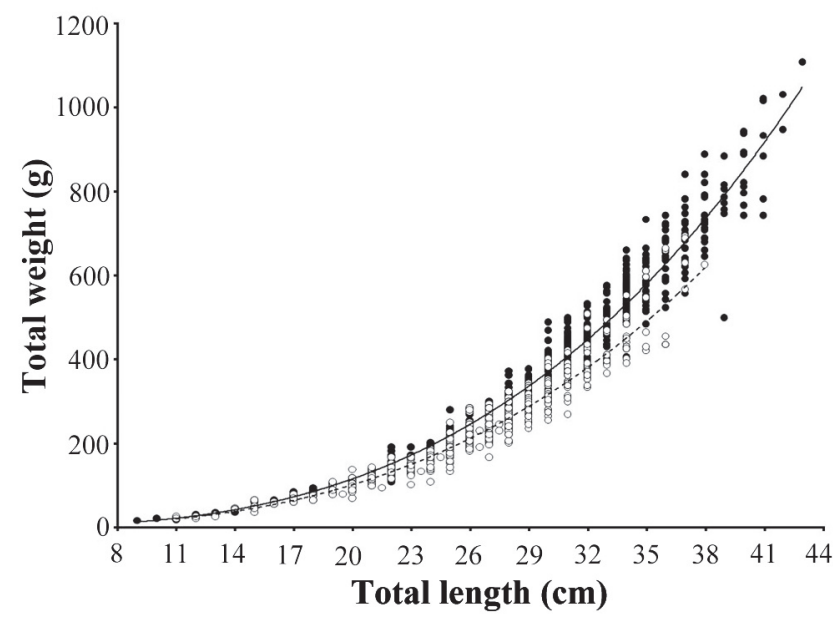

Fig. 5. Relationship between total length (TL) and total weight (TW) for Discopyge tschudii. Males $(\bullet)$ : TW(continuous line $)=0.02 \mathrm{X} \mathrm{LT}^{2.899} ; \mathrm{R}^{2}=0.97 ; \mathrm{n}=556$. Females $(\mathrm{o}): \mathrm{TW}($ dotted line $)=0.021 \mathrm{X} \mathrm{LT}^{2.835} ; \mathrm{R}^{2}=0.97 ; \mathrm{n}=480$.

might not be encompassing the whole population range of this species in the gulf. Despite the variations in the mean number and proportion in each stratum, the northern and eastern areas seem to be the main distributional areas of $D$. tschudii in SMG.

In these areas of SMG, males and females were not equally distributed. While males predominated in the east, females did so in the north. Sexual segregation is a behavior widely documented in elasmobranch fishes (Mellinger, 1971; Sims, 2005; Wearmouth \& Sims, 2008). The proportion of D. tschudii females collected in the Argentine continental shelf decreases as depth increases (Menni et al., 1981). Menni et al. (1981) proposed that sexual segregation in $D$. tschudii might be related to depth. According to the differences found in the distribution of males and females in the present work, sexes in SMG might be using habitats with different hydrological

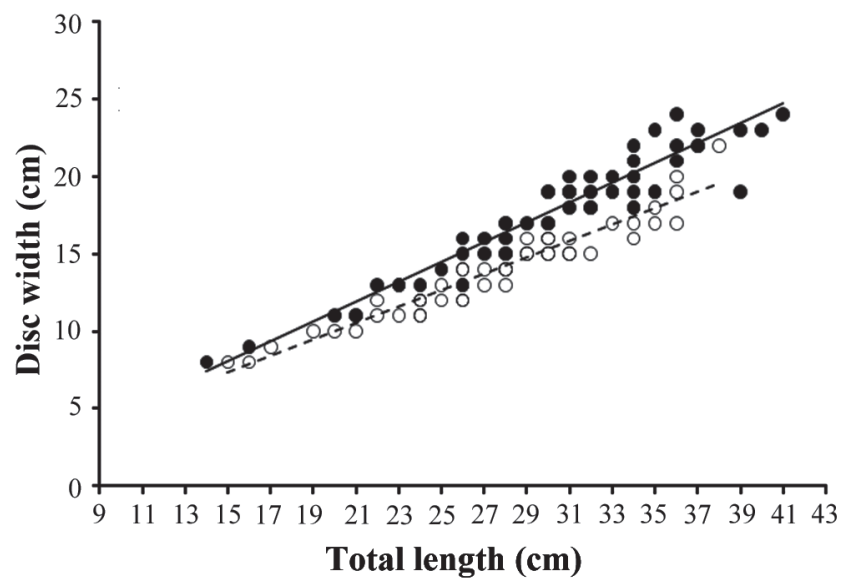

Fig. 6. Relationship between total length (TL) and disc width (DW) for Discopyge tschudii. Males (•): DW(continuous line $)=0.638 \times T L-1.478 ; \mathrm{R}^{2}=0.91 ; \mathrm{n}=71$. Females $(\mathrm{o})$ : $\mathrm{DW}($ dotted line $)=0.531 \times T L-0.633 ; \mathrm{R}^{2}=0.94 ; \mathrm{n}=87$.

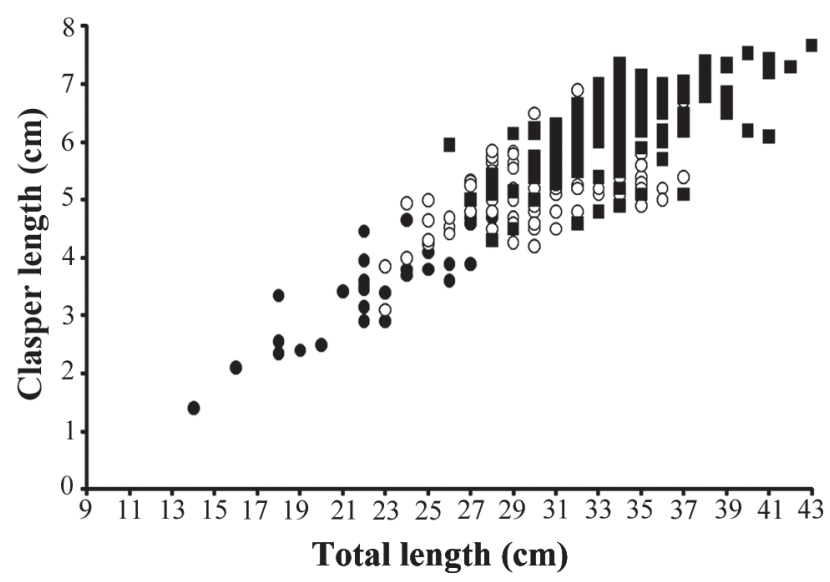

Fig. 7. Relationship between total length and length of the clasper for Discopyge tschudii. Males: immature $(\bullet) \mathrm{n}=34$; maturing $(\mathrm{O}) \mathrm{n}=98$ and mature $(\boldsymbol{\square}) \mathrm{n}=145$.

of 120 m (Menni et al., 1981; Menni \& Gosztonyi, 1982; Pequeño \& Lamilla, 1993; Jaureguizar et al., 2006).

The proportion and the mean number of individuals per haul showed differences in each stratum depending on the decade. Moreover, a low number of individuals were recorded during the 1990's. Two main sources of bias could be affecting these results. One of these sources is the difference in the number of hauls assigned to each stratum in the different decades. For example, a total of 17 hauls were performed in stratum VI during the 1980's. This number was reduced to seven during the 1990's and to zero during the 2000's. In contrast, the number of hauls performed in stratum II increased from 17 in the 1980 's to 27 in the 2000's. The other possible source of bias could be the fact that research surveys were designed to assess the status of the common hake and the other demersal fish resources. So, these research surveys 


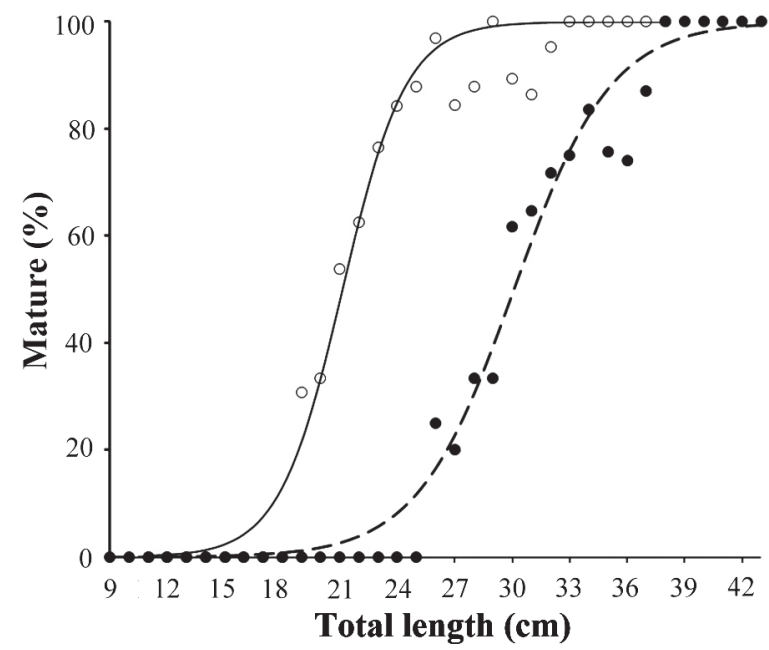

Fig. 8. Size at maturity $\left(\mathrm{TL}_{50 \%}\right)$ of Discopyge tschudii. Males (๑): $\mathrm{TL}_{50 \%}$ (continuous line): $30 \mathrm{~cm} ; \mathrm{R}^{2}=0.98 ; \mathrm{n}=506$. Females (o): $\mathrm{TL}_{50 \%}\left(\right.$ dotted line): $21 \mathrm{~cm} ; \mathrm{R}^{2}=0.98 ; \mathrm{n}=419$.

and ecological characteristics. Nevertheless, further studies focused on the main distributional area of $D$. tschudii should be conducted before reaching a conclusion.

In the present study, mature individuals of $D$. tschudii dominated the samples. García (1984) also recorded the absence of individuals smaller than $20 \mathrm{~cm}$ for samples collected in the area of Mar del Plata $\left(38^{\circ} 021^{\prime \prime} 23^{\prime \prime} \mathrm{S} 57^{\circ} 33^{\prime \prime} 21,03^{\prime \prime W}\right.$; Buenos Aires Province). Two hypotheses have been proposed to explain the predominance of mature individuals in samples; a bias due to the fishing method used and the segregation of immature individuals (García, 1984). In this study, neither of these two hypotheses could be discarded.

Our results show that D. tschudii presents sexual dimorphism. In agreement with that found by García (1984),

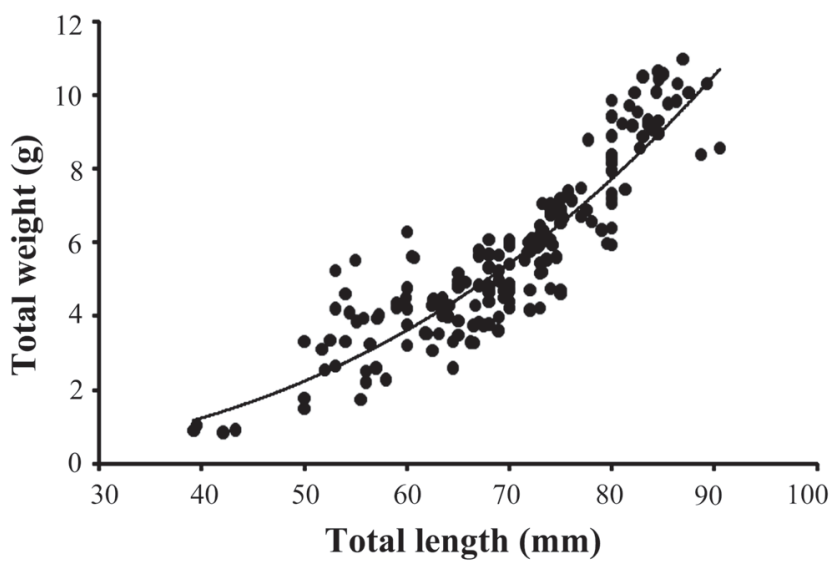

Fig. 10. Relationship between total length $\left(\mathrm{TL}_{e}\right)$ and weight $\left(\mathrm{W}_{e}\right)$ for embryos of Discopyge tschudii. $\mathrm{W}_{e}($ dotted line $)=7 \mathrm{x}$ $10^{-0.5} \mathrm{X} \mathrm{TL}_{e}^{2.63} ; \mathrm{R}^{2}=0.80 ; \mathrm{n}=178$.

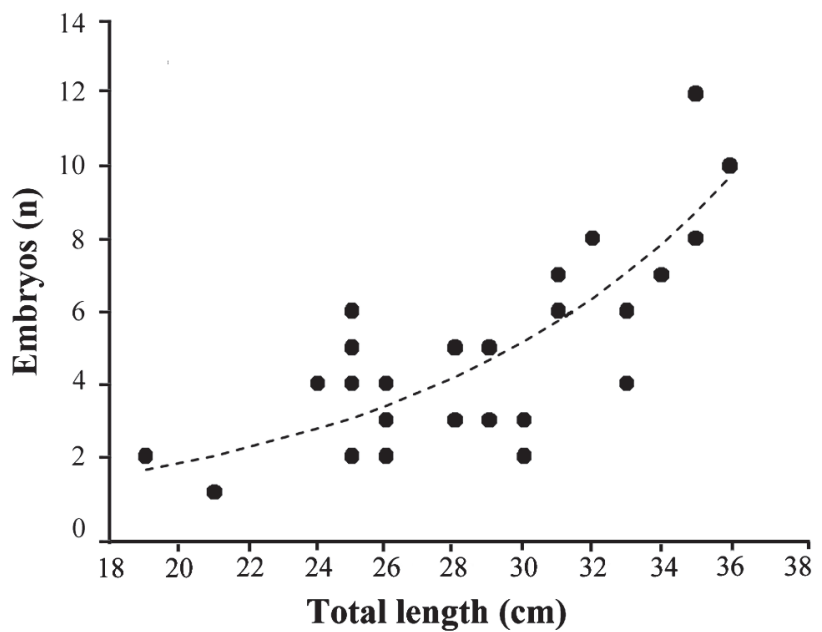

Fig. 9. Relationship between total length of the female (TL) and number of embryos $\left(\mathrm{N}_{e}\right)$ for Discopyge tschudii. $\mathrm{N}_{e}$ (dotted line $)=0.221 \times \exp ^{(0.589 \times \mathrm{TL})} ; \mathrm{R}^{2}=0.57 ; \mathrm{n}=27$.

males were found to be larger and heavier and to mature at larger sizes than females. In addition, Pequeño et al. (1988) found that sexes also differ in the shape and location of their pelvic fins and in the size of the electric organ. In general, chondrichthyan females present larger sizes and are heavier than males (Mellinger, 1989). This characteristic is also widely spread among species of the suborder Torpedinoidei. For example, for Torpedo torpedo (Capapé et al., 2000; Consalvo et al., 2007), T. marmorata (Mellinger, 1989; Consalvo et al., 2007), T. nobiliana (Capapé et al., 2006), T. californica (Neer $\&$ Caillet, 2001) and T. macayana (Capapé et al., 2001) females are larger than males. Males are larger than females only in a few species of chondrichthyans, including $D$. tschudii.

One particular finding of this study is that individuals collected in SMG are smaller than those collected in the area

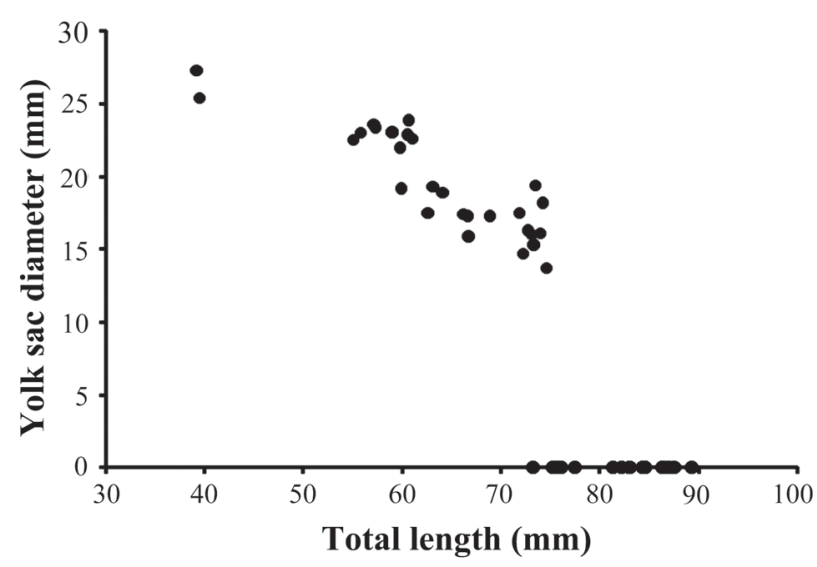

Fig. 11. Relationship between total length of embryos and external yolk sac diameter $(n=49)$. 
of Mar del Plata (García, 1984). Furthermore, size at maturity also differs between studies. While García (1984) reported that the smallest mature male was $32 \mathrm{~cm} \mathrm{TL}$, in our study we found that it was $26 \mathrm{~cm}$ TL. García (1984) also reported that the smallest female with embryos was $27.5 \mathrm{~cm} \mathrm{TL}$, while in our study we found that it was $19 \mathrm{~cm}$ TL. Since both studies were carried out more than 25 years apart, it is difficult to reach a conclusion. In SMG, other batoids, the skates P. lentiginosa and $S$. bonapartii, have experienced significant changes in their size frequency structures towards smaller sizes during the 1990's-2000's period (Estalles pers. obs.). These changes seem to be connected to fishing. Since only a few individuals of D. tschudii were collected during the 1990's, comparisons could not be made. As in the case of the other batoids, $D$. tschudii could have experienced changes in their sizes between decades. Another possible explanation could be that the individuals from Mar del Plata and the ones from SMG belong to different populations with differences in their morphological characteristics. Differences between individuals along a latitudinal gradient have been widely reported for many batoids (Frisk, 2010). However, it is also notable that despite the differences in size at maturity and maximum total length, both studies coincide in size at birth and the number of embryos per litter.

Our study revealed the presence of individuals of a wide range of lengths and in different reproductive stages. It also revealed the presence of females with embryos in different stages of development, including some that could be considered close to birth (external yolk sac completely absorbed and size similar to that of the smallest free swimming individual). These findings allow us to hypothesize that $D$. tschudii completes its reproductive cycle in San Matías Gulf.

\section{Acknowledgements}

We thank Miguel Camarero, Gimena Mora, and Bettiana Rivero for field assistance, and the IBMP Onboard Observer Program for providing us the specimens. We also thank Tec. Elaine Costa Vaz for the translation of the abstract into Portuguese. This study was supported by Universidad Nacional del Comahue Grant: Condrictios del Golfo San Matías: Biología, Ecología y Explotación Pesquera 04/M017, Ministerio de la Producción of Provincia de Río Negro and Agencia de Promoción Científica y Técnica. This was a contribution of the Group of Study of Chondrichthyan Fishes CONDROS.

\section{Literature Cited}

Capapé, C., O. Guélorget, Y. Vergne \& J. Quignard. 2006. Biological observations on the black torpedo, Torpedo nobiliana Bonaparte 1835 (Chondrichthyes: Torpedinidae), from two Mediterranean areas. Annales, series Historia Naturalis, 16: 19-28.

Capapé, C., A. A. Seck \& Y. Diatta. 2000. Reproductive biology of the common torpedo, Torpedo torpedo (Linnaeus, 1758) (Pisces, Torpedinidae) from the coast of Senegal, (Eastern Tropical Atlantic). Miscellània Zoològica, 23: 9-21.
Capapé, C., A. A. Seck, Y. Diatta \& M. Diop. 2001. Observations on the reproductive biology of Torpedo (Tetronarce) macayana (Torpedinidae), from the coast of Senegal (Eastern Tropical Atlantic). Cybium, 25: 95-99.

Compagno, L. J. V. 1984. FAO species catalogue. Sharks of the world. An annotated and illustrated catalogue of shark species known to date. Part I. Hexanchiformes to Lamniformes. FAO Fisheries Synopsis, 125: 1-249.

Consalvo, I., U. Scacco, M. Romanelli \& M. Vacchi. 2007. Comparative study on the reproductive biology of Torpedo torpedo (Linnaeus, 1758) and Torpedo marmorata (Risso, 1810) in the central Mediterranean Sea. Scientia Marina, 71: 213-222.

Di Giácomo, E. E. \& M. R. Perier. 1991a. Abundancia, estructura poblacional y zona de desove de la merluza común (Merluccius hubbsi) en el Golfo San Matías, Argentina. Frente Marítimo 12: 47-52.

Di Giácomo, E. E. \& M. R. Perier. 1991b. Evaluación de la biomasa y explotación comercial del Pez Gallo (Callorhynchus callorhynchus) en el Golfo San Matías, Argentina. Frente Marítimo 12: 7-13.

Di Giácomo, E. E. \& M. R. Perier. 1992. Retracción de la pesquería demersal del golfo San Matías: ¿Escasez de recursos o disminución de la eficiencia?. Frente Marítimo, 11:7-13.

Figueiredo, J. L. 1977. Manual de Peixes Marinhos do Sudeste do Brasil. I.- Introdução. Cações, raias e quimeras. Museu de Zoologia, Universidade do São Paulo, São Paulo, Brazil, 104p.

Francis, M. P. 2006. Morphometric minefieldstowards a measurement standard for chondrichthyan fishes. Environmental Biology of Fishes, 77: 407-421.

Frisk, M. G. 2010. Life history strategies of batoids. Pp. 283-316. In: Carrier, J. C.; J. A. Musick \& M. R. Heithaus (Eds). Sharks and their relatives II: Biodiversity, adaptive physiology and conservation. CRC Press, New York, USA.

García, M. L. 1984. Sobre la biología de Discopyge tschudii (Chondrichthyes, Narcinidae). Physis (Buenos Aires), Sección A, 42: 101-112.

Holden, M. J. \& D. F. S. Raitt. 1975. Manual de Ciencia Pesquera. Parte II. Métodos para investigar los recursos y su aplicación. Documentos Técnicos de la FAO sobre la pesca No 115,211 .

Jaureguizar, A. J., R. Menni, C. Lasta \& R. Guerrero. 2006. Fish assemblages of the northern Argentine coastal system: spatial patterns and their temporal variations. Fisheries Oceanography, 15: 326-344.

Massa, A. M., N. Hozbor \& J. Lamilla. 2004a. Discopyge tschudii. In: IUCN 2010. IUCN Red List of Threatened Species. Version 2010.4. Available from: http://www.iucnredlist.org/ (31 December 2010).

Massa, A. M., L. O. Lucifora \& N. M. Hozbor 2004b. Condrictios de la región costera bonaerense y uruguaya. Pp. 85-100. In: Sánchez, R.P. \& S. I. Bezzi. (Eds.). El Mar Argentino y sus recursos pesqueros. 4. Los peces marinos de interés pesquero. Caracterización biológica y evaluación del estado de explotación. Instituto Nacional de Investigación y Desarrollo Pesquero, Mar del Plata, Argentina, 360p.

Mellinger, J. 1971.Croissance et reproduction de la Torpille (Torpedo marmorata). I. Introduction. Ecologie. Croissance générale et dimorphisme sexual. Cycle. Fécondité. Bulletin Biologique de la France et de la Belgique, 105: 165-218.

Mellinger, J. 1989. Reproduction et developpement des chondrichthyens. Océanis, 15: 283-308.

Menni, R. C. \& A. E. Gosztonyi. 1982. Benthic and semidemersal fish associations in the Argentine Sea. Studies on Neotropical Fauna and Environment, 17: 1-29. 
Menni, R. C., A. J. Jaureguizar, M. F. W. Stehmann \& L. O. Lucifora. 2010. Marine biodiversity at the community level: zoogeography of sharks, skates, rays and chimaeras in the southwestern Atlantic. Biodiversity and Conservation, 19: 775-796.

Menni, R. C. \& H. López. 1984. Distributional patterns of argentine marine fishes. Physis (Buenos Aires), Sección A, 42: 71-85.

Menni, R. C., H. L. López \& M. L. García. 1981. Lista comentada de las especies de peces colectadas durante la campaña $\mathrm{V}$ del B/ I "Shinkai Maru" en el Mar Argentino (25/8-15/9/1978). In: Campañas de Investigación Pesquera realizadas en el Mar Argentino por los B/I "Shinkai Maru" y "Walther Herwig" y B/P "Marbug", años 1978 y 1979. (Angelescu, V. ed.). Contribuciones del Instituto Nacional de Investigaciones y Desarrollo Pesquero INIDEP, No 383, 267-280.

Menni, R. C., G. Rincón \& M. L. García. 2008. Discopyge castelloi sp. nov. (Torpediniformes, Narcinidae), una nueva especie de raya eléctrica del Mar Argentino. Revista del Museo Argentino de Ciencias Naturales, n.s., 10: 161-171.

Menni, R. C. \& M. Stehmann. 2000. Distribution, environment and biology of batoid fishes off Argentina, Uruguay and Brazil. A review. Revista del Museo Argentino de Ciencias Naturales, n.s., 2: 69-109.

Neer, J. A. \& G. M. Cailliet. 2001. Aspects of the life history of the pacific electric ray, Torpedo californica (Ayres). Copeia, 2001: 842-847.

Pauly, D. 1984. Fish population dynamics in tropical waters: A manual for use with programmable calculators. International Center for Living Aquatic Resources Management Studies and Reviews, Manila, Philippinis 8, 325p.

Pequeño, G. R. \& J. G. Lamilla. 1993. Batoideos comunes a las costas de Chile y Argentina- Uruguay (Pisces: Chondrichthyes). Revista de Biología Marina, Valparaíso, 28: 203-217.

Pequeño, G. R., R. Navarro \& J. Oporto. 1988. Discopyge tschudii Heckel 1845: Aporte a su taxonomía con hincapié en su dimorfismo sexual (Chondricthyes, Narcicinidae). Estudios Oceanológicos, 7: 41-50.
Perier, M. R. \& E. E. Di Giácomo. 2002a. El Savorín Seriolella porosa, como un recurso estacional en el Golfo San Matías, República Argentina. Revista de Investigación y Desarrollo Pesquero 15: 15-26.

Perier, M. R. \& E. E. Di Giácomo. 2002b. Distribución, abundancia y reproducción de Paralichthys isosceles, P. patagonicus y Xistreuris rasile (Pleuronectiformes: Bothidae) en aguas patagónicas, Argentina. IBMP - Serie Publicaciones, 1: 32-39.

Prager, M. H., S. B. Saila \& Recksiek, C. W. 1989. FISHPARM: a microcomputer program for parameter estimation of nonlinear models in fishery science, second edition. Old Dominion University Oceanography Technical Report, 87-10.

Sims, D. W. 2005. Differences in habitat selection and reproductive strategies of male and female sharks. Pp. 127-147. In: Ruckstuhl, K. E. \& P. Neuhaus (Eds.). Sexual segregation in vertebrates: Ecology of the two sexes. Cambridge University Press, United Kingdom, 500p.

Sokal, R. R. \& F. J. Rohlf. 1987. Biometría. Principios y métodos estadísticos en la investigación biológica. H. Blume Ediciones, Madrid, España, 832p.

Stehmann, M. F. W. 2002. Proposal of maturity stages scale for oviparous and viviparous cartilaginous fishes (Pisces, Chondrichthyes). Archive of Fishery Marine Research, 50: 23- 48.

Tamini, L. L., G. E. Chiaramonte, J. E. Perez \& H. L. Cappozzo. 2006. Batoids in a coastal trawl fishery of Argentina. Fisheries Research, 77: 326-332.

Wearmouth, V. J. \& D. W. Sims. 2008. Sexual segregation in marine fish, reptiles, birds and mammals: Behaviour patterns, mechanisms and conservation implications. Advances in Marine Biology, 54: 107-170.

Zar, J. H. 1984. Biostatistical Analysis, Second Edition. Prentice Hall, Englewood Cliffs, USA, 718p.

Submitted February 6, 2011 Accepted October 22, 2011 Published December 26, 2011 